\title{
Leadership for Education in a Digital Age
}

\author{
Svetlana Ivanovna Fedorova ${ }^{11}$, Yulia Sergeyevna Krylova ${ }^{2}$, Antonina Yuryevna Nesterova ${ }^{3}$, \\ Viktoria Sergeyevna Plotnikova ${ }^{4}$, and Galina Mikhailovna Yanushkina ${ }^{4}$ \\ ${ }^{1}$ Ulyanovsk State Agrarian University named after P. A. Stolypin, Department of Pedagogy and \\ Psychology, Ulyanovsk, Russia \\ ${ }^{2}$ Petrozavodsk State Glazunov Conservatoire, College, Petrozavodsk, Russia \\ ${ }^{3}$ Russian State University for the Humanities, Department of Pedagogy and Psychology, Moscow, \\ Russia \\ ${ }^{4}$ Petrozavodsk State University, Department of Tourism, Petrozavodsk, Russia
}

\begin{abstract}
The article deals with some pedagogical aspects of the digitalization of education. The idea of a digital teacher as the leader of digital educational activity is in the focus of the theoretical analysis presented in the article. It is noted that knowledge and information, together with sustainability initiatives, organizational and technological innovations, start-ups, next-practice platforms, smart solutions, systems, technologies and instruments, etc., have become the present-day key drivers of innovative educational platforms, online courses, digital textbooks, etc. influence on the transformation of the educational environment. Education is becoming more personalized. The content of teaching and learning is being changed radically according to its new values, meanings, orientations, as well as educational and pedagogical discourses. It is stressed in the article that teacher's digital skills and competencies should be identified as the key professional pedagogical skills and competencies for his or her life-long learning, professional development and professional growth due to the challenges of the $21^{\text {st }}$-century knowledge, information and innovations society and education. As it is stated in the article, to fulfill a system of professional-pedagogical and educational functions more effectively and to guarantee the optimal implementation of information and communication technologies. It is quite necessary for teachers to have adequate skills and competencies that characterize his or her digital professional culture of teaching.
\end{abstract}

Keywords: educational paradigm, professional activity of a teacher, digital teacher, digital school, digital educational environment

\section{$1 \quad$ Introduction}

The problem of theoretical analysis of the leadership activity of teachers and educational institutions is determined by the specifics of the modern trends of the development of education as a basic resource of social and human capital in the digital age. Global

\footnotetext{
${ }^{1}$ Corresponding author: fedorov.mpgu@yandex.ru
} 
socio-cultural shifts, transformation and systemic changes in social relations require the fundamental basis for the formation of a new civilizational culture as the culture of a post-industrial society based on knowledge, information, and innovative technologies.

A new mission of education, its vision, values and meanings are being formed and developed under these conditions. The repertoire of socio-cultural roles of teachers and educational institutions is updated and improved. The key mission of the changing and transforming education for the $21^{\text {st }}$ century is tightly connected with the creation of new literacies, skills, and competencies, such as a value-semantic competence, an information competence, a competence of cognition (critical thinking), a competence of new ways of interacting with the other people (collaboration, co-operation, team activity, etc.); a competence of self-management [1].

Ultimately, the changes in the goals of the educational policy of the Russian Federation (National Project "Education" for 2019-2024), the European Union (European Policy Cooperation "ET 2020 Framework"); Commission Staff Working Document "Proposal for a Council Recommendation on Key Competencies for Life Long Learning", and the OECD countries determine shifts and transformations of the socio-cultural image and landscape of education. This, in turn, serves as a fundamental basis for the formation of a new paradigm of the activity of educational institutions and acts as a key factor determining the nature, direction, content and mechanisms of institutionalization of the managerial activity as an integrity of educational administration, management and leadership.

\subsection{Problem statement}

One of the value dominants of the formation and development of education for the $21^{\text {st }}$ century is the consolidated participation of the educational, pedagogical and parent community, students, state and municipal executive authorities, business, as well as representatives of local communities in solving the problems of developing and changing education to meet the challenges of a post-industrial society based on knowledge, information, and innovation [2].

Public-state partnership plays an increasing role in managing the development of the quality of education in transition.

The transforming management and leadership activity becomes one of the key resources of the strategic development of the educational organization. It becomes the most important tool of innovations aimed at achieving a new quality of education [2-8].

\section{$1.2 \quad$ Literature review}

Education, as one of the basic cultural and social institutions, has ever ensured the development of human resources [3, 4, 9-16].

Knowledge and information, together with sustainability initiatives, organizational and technological innovations, start-ups, next-practice platforms, smart solutions, systems, technologies and instruments, etc., have become the present-day key drivers of innovations [17-19].

The interdisciplinary problem of key skills and competencies for the $21^{\text {st }}$ century is actively discussed [1, 9, 20-26].

The authors pay special attention to the fact that the key competencies, such as critical thinking, creative thinking, the ability to communicate and the ability to work in a team, under the conditions of joint activities and cooperation, will be of great demand in the nearest future. 
The professional skills and competencies of a teacher in the changing educational environment are also of great research and practical interest. Teaching and learning to teach can be defined as complex, multifaceted, value-laden social activities against the global backdrop of the "digital" knowledge society. The continuum of teacher training from a life-long learning perspective implies the need for an extended professionalism of a teacher. On the other hand, the content of teacher professionalism is changing greatly because of the influence of changing educational environment and educational discourses based on quite new values and meanings of the teacher's professional activity [9, 21, 25-28].

Different aspects of leadership are represented by Allix, Bush, Fullan, Johnson, Leithwood, et al. [2, 4, 5, 8, 15, 24, 29-31]. They state the fact that the nature of management and leadership activity is changing nowadays.

According to the results of the International Organization for Economic Cooperation and Development (OECD) comparative monitoring of the quality of general education (including the management aspect), conducted with the participation of the Russian Federation in 2008, 2013, and 2018 within the framework of the TALIS project, leaders of educational organizations in Russia are less engaged directly in the educational management and leadership and in the implementation of positive management leadership practices. They have deficits in organizing interaction with the external environment of the educational organization $[1,20]$.

\subsection{Research questions and purpose of the study}

In this study, the main focus was made on the peculiarities of educational management and leadership in a changing educational system. It became the purpose of the study.

\section{$2 \quad$ Methods}

The study included an analysis of the present-day state policy of the Russian Federation in the development of education, a factor analysis of determinants of educational management and leadership in transition and a theoretical reflection of the main drivers and trends that determine innovations and systemic changes of educational management and leadership.

\section{$3 \quad$ Results and discussion}

Management and leadership activity is always associated with the processes of change and development. It is characterized by its specific multidisciplinary dimension and unique subject-subject nature, as it involves developing managerial and leadership interaction to solve various management tasks of various types and levels in accordance with the internal capabilities of the organization and the need for its constant adaptation to changes in the external environment $[9,20,21]$.

In the context of the global transformation of the SPOD world and the rapid formation of new social and economic relations that characterize the VUCA world, the dynamism and uncertainty of the factors and processes of management and leadership activities significantly increase.

The mechanism of socio-cultural development, as well as the characteristics of the situation of implementing managerial and leadership activities, have been changed. The normative element of management and leadership (prescriptions, norms, regulations, guidelines, etc.) has been replaced by innovation in solving managerial and leadership tasks 
under new conditions (new information and communication technologies, network management and leadership interaction, digital transformation of management and leadership processes). This trend is a reflection of the ontologization of management activities with the "blurring" of the subject of management and leadership under the conditions of unpredictability, multivariance and incompleteness of development vectors of managerial and leadership alternatives and managerial risk.

Changes of the mission, values and meanings of an educational organization determine the changes in the socio-cultural image and landscape of education and their corresponding management and leadership practices. They are as follows:

- the transformation of the civilizational paradigm of the development of education, accompanied by a change in the entire system of socio-cultural orientations and meanings within the boundaries of the formation of a new transforming civilization;

- the transformation of interrelated and mutually dependent processes of both personal and professional development, as well as educational and professional life of the individual "throughout life", acquiring a multicultural character;

- the systemic changes in the life and educational space of society and the individual as well as the formation of fundamentally different ways of living and mastering the developing personality of their childhood, adolescence, youth, maturity, which expands the age framework of education - "throughout life" (not only formal, but also non-formal and informal, not only real, but also virtual, media and digital);

- the actualization of the role and significance of academic and socio-professional mobility of society and the individual "throughout life" for solving various life situations that arise by means of education, their reflection from the positions of their own and other cultures;

- the increased competition in the domestic and global markets of cultural and educational services, which, in turn, causes the problem of exporting this category of services;

- the formation of a new type of pedagogical and educational culture in educational organizations, the main elements of which are the following:

(a) assistance in the formation of the essential forces of the developing personality (interests, needs, motives, values, meanings of behavior and life activity);

(b) creation of developing interaction of the subjects of an educational activity;

(c) creation and support of developing educational environment.

The factors that determine the request for a new type of a leader of an educational organization and transform of his or her managerial and leadership activities are as follows:

- institutional changes in the field of education, the development and expansion of the market of educational services and the need to improve the competitiveness of the educational organization;

- strengthening the interaction of the internal environment of the educational organization with the external environment by means of system development and implementation of strategies for its sustainable development and adaptation to system changes and their management;

- further institutionalization of the management activities of the leader of an "effective" educational organization, as a result of the change of the management and leadership paradigm to a new one, due to the transition from the philosophy of forming an educational organization to the philosophy of its strategic development and resource provision as an "open school";

- the need for unity and interaction of the basic functions of management and leadership activities (administration, strategic management, leadership) and their enrichment with new 
content in the process of strategic development in the context of systemic changes and its formation as an open, socially involved, dynamic, mobile, flexible, and accessible educational system;

- a request for the orientation of management and leadership activities to the successful solution of pedagogical, educational, organizational, economic and financial tasks that contribute to the improvement of organizational-economic mechanisms of management and strategic development of an educational organization;

- the formation of the concept of strategic management of an educational organization in the context of its systemic changes as a developing educational space and involvement and participation of all subjects and stakeholders of educational activity, local communities, society, as a whole.

\section{Conclusion}

The authors are quite convinced that the study of the transformations of the managerial and leadership activity in an educational organization in the context of global shifts and systemic changes in education is very timely, having scientific and practical significance, as well as social and professional demand.

Pedagogical science still does not have a complete, systematic, scientifically based theory of the educational management and leadership activity in the conditions of transformation of education.

The results of the study were used in design and implementation of new educational courses on the Theory and Practice of Education and Management of Education in the Russian State University for the Humanities, Ulyanovsk State Agrarian University named after P. A. Stolypin, Petrozavodsk State University, and Petrozavodsk State Glazunov Conservatoire.

\section{References}

1. I.D. Frumin, et al., Mod. Edu. Analyt. 2(19), 1-25 (2018)

2. M. Anderson, Int.Soc. Sci. Rev. 93(1), 4 (2014)

3. S. Balistreri, F.T. Di Giacomo, I. Noisette, T. Ptak, Res. In Rev. 4, (2012)

4. T. Dintersmith, What School Could Be: Insights and Inspiration from Teachers across America (Princeton University Press, 2018)

5. R. Halverson, C. Kelly, J. Shaw, Phi Delta Kappan, 95(6), 57-60 (2014)

6. J. Quinn, et al., J. Lead. Edu. 4(3), 71-85 (2015)

7. M. Ornorato, Acad. Edu. Lead. J. 17(1), 33-47 (2013)

8. J. Pounder, Qual. Assur. Edu. 22(3), 273-285 (2014)

9. M. Asselin, Teaching information skills in the information age: An examination of trends in the middle grades, in M.A. Mardis (ed.), Librarians and educators collaborating for success: The international perspective, 82-100 (Libraries Unlimited, Santa Barbara, CA, 2017)

10. S. Baller, S. Dutta, B. Lanvin (eds.), The Global Information Technology Report 2016. Innovating the Digital Economy. Insight Report. Accessed on: July 20, 2021. [Online]. Available: http://www3.weforum.org/docs/GITR2016/WEF_GITR_Full_Report.pdf 
11. T. Barkatsas, A. Bertram (eds.), Global learning in the $21^{\text {st }}$ century (Sense Publishers, Boston, MA, 2016)

12. J.A. Banks, Cultural diversity and education: Foundations, curriculum, and teaching (Routledge, Taylor \& Francis Group, New York, 2016)

13. E.R. Hollins, Culture in school learning: Revealing the deep meaning (Routledge, New York, 2015)

14. How Digital Technology Has Changed Modern Education. Accessed on: July 20, 2021. [Online]. Available: https://

www.anadea.info/blog/how-digital-technology-has-changed-modern-education

15. D.J. Loveless, P.M. Sullivan, Deconstructing the education-industrial complex in the digital age (IGI Global, Hershey, PA, 2017)

16. R. Patton, R. Santos, The Next-Generation Digital Learning Environment and a Framework for Change for Educational Institution (Cisco Education Lead, Latin America 2018). Accessed on: July 20, 2021. [Online]. Available:

https://www.cisco.com/c/dam/en_us/solutions/industries/docs/education/digital-learnin g-environment.pdf

17. UN Digital Economy Report 2019. Value Creation and Capture: Implications for Developing Countries (United Nations, New York, 2019)

18. Education Transforms Lives (UNESCO, Paris, 2017)

19. Deloitte, Digital Education Survey "After the bell rings: expanding the classroom". Emerging trends in digital education technology devices and materials (Deloitte Development LLC, New York, 2016). Accessed on: July 20, 2021. [Online]. Available: https://www2.deloitte.com/content/dam/Deloitte/us/Documents/technology-media-tele communications/us-tmt-digital-education-survey.pdf

20. K. Ananiadou, M. Claro, OECD Edu. Work Papers, 41 (2009). https://doi.org/10.1787/218525261154

21. M. Binkley, et al., Defining $21^{\text {st }}$ century skills, in P.E. Griffin, B. McGaw, E. Care (eds.), Assessment and Teaching of $21^{\text {st }}$ Century Skills, 17-66 (2018).

https://doi.org/10.1007/978-94-007-2324-5_2

22. Working Group on Education. Digital skills for life and work - 2017. Accessed on: July 20, 2021. [Online]. Available:

http://d-russia.ru/wp-content/uploads/2017/10/Digital-skills-for-life-and-work_259013 e.pdf

23. M.S. Dobryakova, O.V. Yurchenko, E.G. Novikova, Mod. Edu. Anal. 4(21), 1-66 (2018)

24. A. Eargle, $21^{\text {st }}$ Century Skills Leadership and Learning in the $21^{\text {st }}$ Century (Public Schools of North Carolina, 2018)

25. M. Kelentrić, K. Helland, A.-Th. Arstorp, Professional Digital Competence Framework for Teachers (The Norwegian Centre for ICT in Education, 2017)

26. C. Redecker, et al., European Framework for Digital Competence of Educators (Publications Office of the European Union, Luxembourg, 2017). https://doi.org/doi:10.2760/178382

27. B.O. Djumanova, K.Sh. Makhmudov, Sci. Edu. 1(3), 554-557 (2020)

28. T. Bush, Theories of Educational Leadership and Management (SAGE, 2020) 
29. T. Bush, Manag. Edu. 32(2), 66-71 (2018)

30. J. Conrads, M. Rasmussen, N. Winters, A. Geniet, L. Langer, Digital Education Policies in Europe and Beyond. Key Design Principles for More Effective Policies. Accessed on: July 20, 2021. [Online]. Available: https://doi.org/10.2760/462941

31. N.V. Karmazina, A.M. Fedorov, Obrazovanie dlya XXI veka: novye vyzovy $v$ usloviyakh sistemnykh izmenenii [Education for the 21st Century: New Challenges under Systemic Changes], in A.Yu. Nagornova (ed.), Development of Modern Higher Education in Russia and Abroad ("Zebra" Publishing house, Ulyanovsk, 2020) 